\title{
Commentary: Pediatric cardiac stem cells: Another holy grail?
}

\author{
Carl L. Backer, MD
}

From the Department of Surgery, Northwestern University Feinberg School of Medicine, Chicago, Ill; and Division of Cardiovascular-Thoracic Surgery, Ann \& Robert H. Lurie Children's Hospital of Chicago, Chicago, Ill. No funding was provided for this editorial commentary.

Disclosures: Dr Backer is a consultant to W.L. Gore \& Associates, which has no relevance to this editorial.

Received for publication May 23, 2019; accepted for publication May 24, 2019; available ahead of print July 2, 2019.

Address for reprints: Carl L. Backer, MD, Division of Cardiovascular-Thoracic Surgery, Ann \& Robert H. Lurie Children's Hospital of Chicago, 225 E Chicago Ave, mc 22, Chicago, IL 60611 (E-mail: cbacker@ luriechildrens.org).

J Thorac Cardiovasc Surg 2019;158:850

$0022-5223 / \$ 36.00$

Copyright (C) 2019 by The American Association for Thoracic Surgery

https://doi.org/10.1016/j.jtcvs.2019.05.059

I welcome the review article on the use of stem cell therapy in pediatric patients provided by Sano and colleagues ${ }^{2}$ in this issue of the Journal. Wikipedia defines the Holy Grail as a vessel "with miraculous powers that provides happiness and eternal youth.... an elusive object or goal that is sought after for its great significance." ${ }^{3}$ Certainly, that describes the potential power of cardiac stem cells. The opinion piece provided by Sano and colleagues ${ }^{2}$ is a superb review of where this field started and where it is going now. Dr Sano is one of the leading investigators in this field and has been working with stem cells in pediatric patients for many years. This is a very young field, as evidenced by the fact that the oldest reference in the article ${ }^{2}$ is from 2003, and essentially all the other references are from the last 5 years.

The review article of Sano and colleagues ${ }^{2}$ is a focused effort to summarize the recent advances in cardiac stem cell therapy in pediatric patients. One of the primary objectives of stem cell therapy is to increase healthy myocardium, particularly in patients with hypoplastic left heart syndrome and in other patients with single-ventricle morphology with right ventricular dominance. Sano and colleagues $^{2}$ take us through the phase I TICAP (Transcoronary Infusion of Cardiac Progenitor Cells in Patients with Single Ventricle Physiology) and the phase II PERSEUS (Cardiac Progenitor Cell Infusion to Treat Univentricular Heart Disease) trials from Japan. These clinical trials evaluated the safety and feasibility of transcoronary infusion of autologous stem cells. The positive results from TICAP and PERSEUS were a clinical launch for trials of cardiac

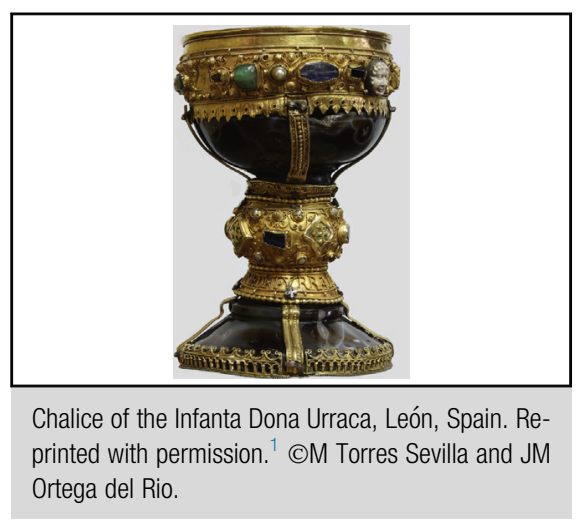

Central Message

A review of cardiac stem cell therapy efforts in pediatric patients shows that further investigation is needed to define timing, dosing, and cell types to help children with complex congenital heart disease.

See Article page 845

regeneration therapy. The authors then summarize the current APOLLON (Cardiac Stem/Progenitor Cell Infusion in Univentricular Physiology), Mayo Clinic, Duke, and ELPIS (Allogeneic hMSC Injection in Patients with Hypoplastic Left Heart Syndrome-University of Maryland) cardiac stem cell trials. It is to be hoped that further investigation will define the ideal timing, dosing, and stem cell types to help children with complex heart disease. Stem cell therapy is indeed an elusive goal, but we seek it because of its great significance for these challenging patients.

\section{References}

1. Torres Sevilla M, Ortega del Rio JM. Kings of the Grail: tracing the historic journey of the cup of Christ from Jerusalem to modern-day Spain. New York: Harry N. Abrams; 2015:256.

2. Sano S, Ishigami S, Sano T. New era of heart failure therapy in pediatrics: cardiac stem cell therapy on the start line. J Thorac Cardiovasc Surg. 2019;158:845-9.

3. Wikipedia. Holy Grail. Available at: https://en.wikipedia.org/wiki/Holy_Grail. Accessed May 21, 2019. 